\title{
Fluid Inclusion Study of Epithermal Quartz Veins from the Kyaukmyet Prospect, Monywa Copper-Gold Ore Field, Central Myanmar
}

\author{
Toe Naing 0o*1,2, Agung Harijoko ${ }^{1}$, Lucas Donny Setijadji ${ }^{1}$ \\ 1 Department of Geological Engineering, Faculty of Engineering, Gadjah Mada University, Yogyakarta, Indonesia \\ 2 Department of Geology, West Yangon University, Yangon, Myanmar
}

\author{
* Corresponding author : toenaingoo.geol84@gmail.com \\ Tel.: +62-812-289-256-46 \\ Received: Sept 16, 2021; Accepted: Dec 31, 2021. \\ DOI 10.25299/jgeet.2021.6.4.7726
}

\begin{abstract}
The Kyaukmyet prospect is located near the main ore bodies of the Kyisintaung and Sabetaung high-sulfidation Cu-Au deposits, Monywa copper-gold ore field, central Myanmar. Lithologic units in the research area are of mainly rhyolite lava, lapilli tuff and silicified sandstone, mudstone and siltstone units of Magyigon Formation which hosted to be polymetallic mineralization. Our field study recorded that epithermal quartz veins are hosted largely in rhyolite lava and lapilli tuff units. Those quartz veins show crustiform, banded (colloform), lattice bladed texture and comb quartz. The main objectives of the present research in which fluid inclusion studies were considered to conduct the nature, characteristics and hydrothermal fluids evolution from the epithermal quartz veins. In this research, there are three main types of fluid inclusions are classified according to their phase relationship (1) two-phase liquid-rich inclusions, (2) the coexisting liquid-rich and vapor-rich inclusions, and (3) only vapor-rich inclusions. Microthermometric measurements of fluid inclusions yielded homogenization temperatures $(\mathrm{Th})$ of $148-282^{\circ} \mathrm{C}$ and final ice-melting temperature $(\mathrm{Tm})$ of $-0.2^{\circ} \mathrm{C}$ to $-1.4^{\circ} \mathrm{C}$. The value of $(\mathrm{Tm})$ are equal to the salinities reaching up 0.35 to $2.07 \mathrm{wt} \% \mathrm{NaCl}$ equiv. respectively. Estimation formation temperature of the quartz veins provide $190^{\circ} \mathrm{C}$ and $210^{\circ} \mathrm{C}$ and paleo-depth of formation are estimated to be between $130 \mathrm{~m}$ and $210 \mathrm{~m}$. Petrography of fluid inclusion and microthermometric data suggest that fluid boiling as well as mixing processes were likely to be happened during the hydrothermal fluid evolution at the Kyaukmyet prospect. According to the characteristics of many parameters including petrography of fluid inclusion, microthermometric data, paleo-depth, evidence of quartz vein textures and types of hydrothermal alteration from the Kyaukmyet prospect allows to interpret these data to be the low-sulfidation epithermal system.
\end{abstract}

Keywords: Kyaukmyet, epithermal quartz veins, fluid inclusions, formation temperature, paleo-depth, Monywa copper-gold ore field

\section{Introduction}

The Kyaukmyet prospect is a well-known for a low sulfidation (LS) epithermal deposit which situated in the western part of Chindwin River (Monywa City), Monywa copper-gold ore field, which is belonged to the WunthoPopa magmatic arc (also known as Wuntho Popa arc), central Myanmar (Figure 1,2). In general, Monywa coppergold ore field is a very foremost epithermal copper-gold deposit as recognized by its the second largest deposit in the South East mainland Asia and ore containing more than $7 \times 10^{7}$ tons of $\mathrm{Cu}$ and 3 to $10 \mathrm{~g} / \mathrm{t} \mathrm{Au}$ (Htet, 2008; A. H. G. Mitchell et al., 2011; Zaw, Swe, Myint, \& Knight, 2017). The prospect area was discovered by Ivanhole Copper Company Limited in 1995 during the extensive exploration in the search for $\mathrm{Cu}-\mathrm{Au}$ deposit, $\mathrm{Au}-\mathrm{Ag}$ deposit and base metals mineralization in the Monywa copper-gold ore field. An exploration program discovering of copper-gold and polymetallic mineralization had been searched by based on the detailed on geological and geophysical investigation. Geologically, the prospect area is mainly composed of rhyolite lava, lapilli tuff and silicified sandstone, mudstone and siltstone units (Figure 3). On the basis of field investigation, the characteristics and different types of epithermal quartz veins observed such as banded (colloform) quartz vein, crustiform quartz vein, comb quartz and lattice bladed texture in the Kyaukmyet prospect is shown in (Figure 4). Those quartz veins are trending nearly ENE-WSW direction because of controlling regional structure. Htet, (2008) and Naing Oo, Harijoko, \& Setijadji, (2021)reported that a typical characteristics of quartz vein textures as well as minor adularia at Kyaukmyet prospect remark on a LS epithermal deposit.

Previous research has also demonstrated that, in the Kyaukmyet prospect area of ore mineralization had occurred in veins, filling structurally in weak fractures (Htet, 2008). The mineralized veins commonly show complex nature of brecciation, banding, vuggy, comb and lattice bladed texture. Moreover, mineralization veins are found in silicified zone where gold is intimately associated with base metals sulfide mineral assemblages along with gangue mineral assemblages consisting mainly of quartz, adularia, sericite and calcite (Htet, 2008; Naing Oo et al., 2021). The rhyolite lava as well as lapilli tuff rock units in the Kyaukmyet prospect are mainly recognized by distinct alteration mineral assemblages and zoning which are associated with areas of epithermal gold mineralization. Most common hydrothermal alterations in the research area are silicic alteration (quartz, adularia, calcite, pyrite), argillic alteration (illite, illite/smectite, quartz, sericite, chlorite) and propylitic alteration (chlorite, epidote, quartz pyrite) (Htet, 2008; Naing Oo et al., 2021). This paper aims to emphasize study on fluid inclusion of epithermal quartz 
veins from the Kyaukmyet prospect especially to determine the formation temperature, trapping pressure, paleo-depth, density and to identify the characteristics of hydrothermal fluid condition.

\section{Geologic Setting}

Myanmar is situated in mainland of Southeast Asia and prosperous in mineral resources and a very complex tectonic region which lie in the eastern boundary of IndiaAsia collision zone and characterized by a well-known right lateral movement of Sagaing Fault. A. H.G. Mitchell et al., (2007), Searle et al., (2007) and Lee, Chung, \& Yang, (2016) reported that they are tectonically connected to the eastern tip of Alpine Himalayan to the north as well as the Andaman Sea to the south (Figure 1). Based on the tectonic events, Myanmar can be classified into two distinct tectonic provinces including the eastern province as well as the western province (Liu et al., 2016). The eastern part is made up of the Mogok Mandalay Mergui Belt and the Shan Plateau whereas the western part is composed of the Wuntho-Popa magmatic arc and the Indo-Myanmar Ranges (Figure 1). In general, a N-S trending of the Wuntho-Popa magmatic arc has played a prominent geological factor and a very important mineral resources in Myanmar. In deep, the Wuntho Popa magmatic arc has belonged to different type of mineral deposits, such as HS type epithermal copper-gold deposit, LS epithermal deposit and Mesothermal gold deposit (Htet, 2008; A. H. G. Mitchell et al., 2011; Naing Oo et al., 2021; Zaw, 1990; Zaw et al., 2017). Geologically, it is characterized by the occurrence of both Mesozoic volcanic and intrusive rocks which are widely distributed by Cretaceous-Pliocene sedimentary formations. Accordingly, the Wuntho Popa magmatic arc is composed dominantly of Upper Cretaceous to Tertiary granodioritic intrusive rocks, and with minor part of volcanic rocks of Upper Cretaceous to Quaternary ages (A. Mitchell, Chung, Oo, Lin, \& Hung, 2012; A. H. G. Mitchell et al., 2011; Zaw et al., 2017).

The Monywa copper-gold ore field is located within the Wuntho Popa magmatic arc, central part of Myanmar (A. H. G. Mitchell et al., 2011; Zaw, 1990; Zaw et al., 2017) (Figure 1). In the Monywa copper-gold ore field, Mesozoic volcanic rocks are mainly intruded by Upper Cretaceous age of granodiorites (A. H. G. Mitchell et al., 2011). Based on the previous research (Htet, 2008; A. H. G. Mitchell et al., 2011), the Monywa copper-gold ore field of high-sulfidation (HS) copper-gold deposit and low-sulfidation (LS) gold-silver deposit in the Monywa copper-gold ore field are spatially and temporally related to basement rocks as well as granitic intrusions. Meanwhile, the basement rocks are widely spread out by volcanic rocks such as andesite, quartz andesite porphyry, dacite, and rhyolite (Figure 2). Most copper-gold (high-sulfidation type) and gold-silver (lowsulfidation type) deposits between the Chindwin River and Powintaung are mainly formed by the Late Oligocene to Middle Miocene Magyigon Formation as well as porphyry intrusions (Figure 2).

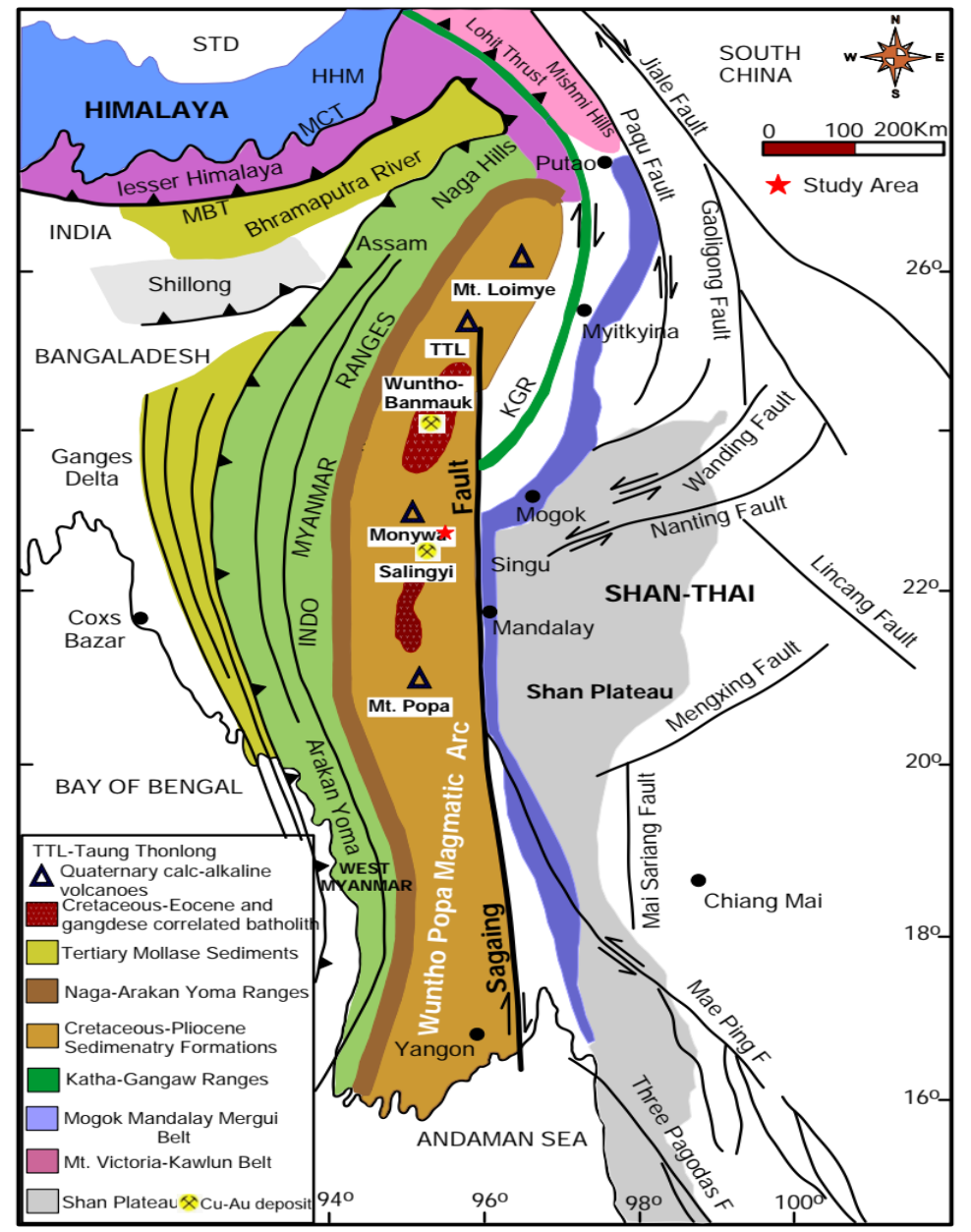

Fig 1. Simplified geological map of Myanmar illustrating outline of Wuntho Popa magmatic arc, principal tectonic units and major Quaternary calc-alkaline volcanoes (modified after Lee et al., 2016; Searle et al., 2007). 


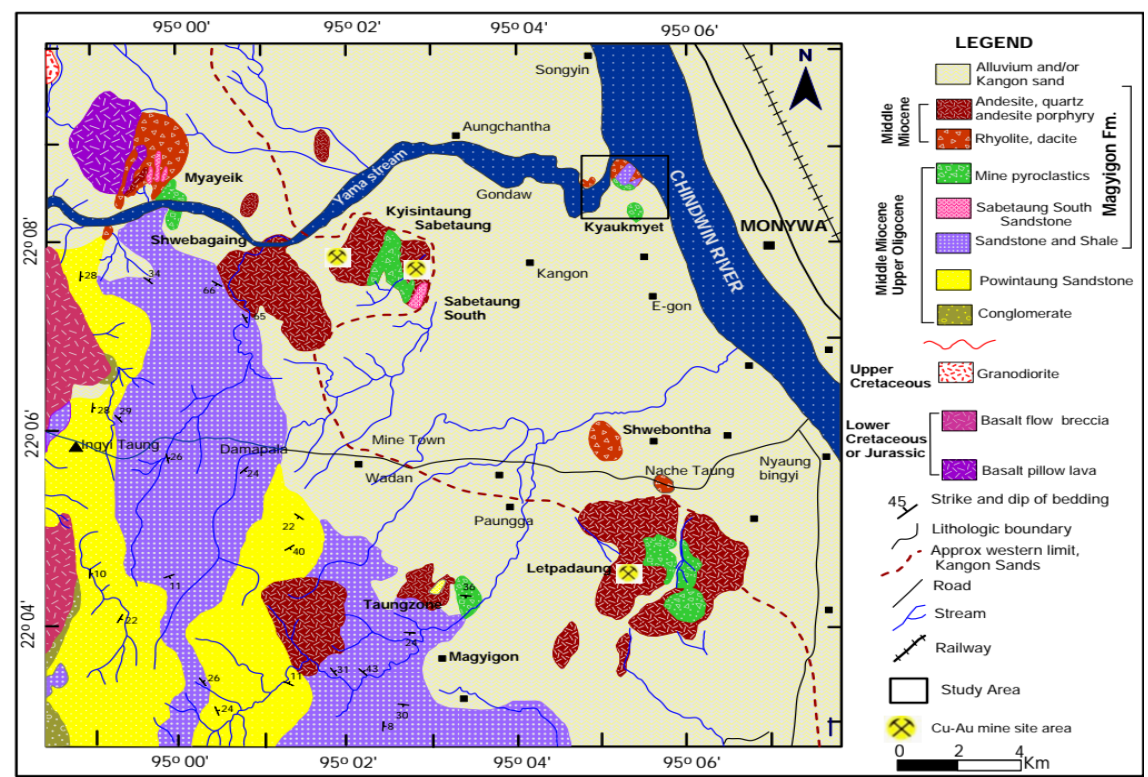

Fig 2. Regional geological map of the Monywa copper-gold ore field and the black rectangle is the Kyaukmyet prospect (Modified after A. H. G. Mitchell et al., 2011).

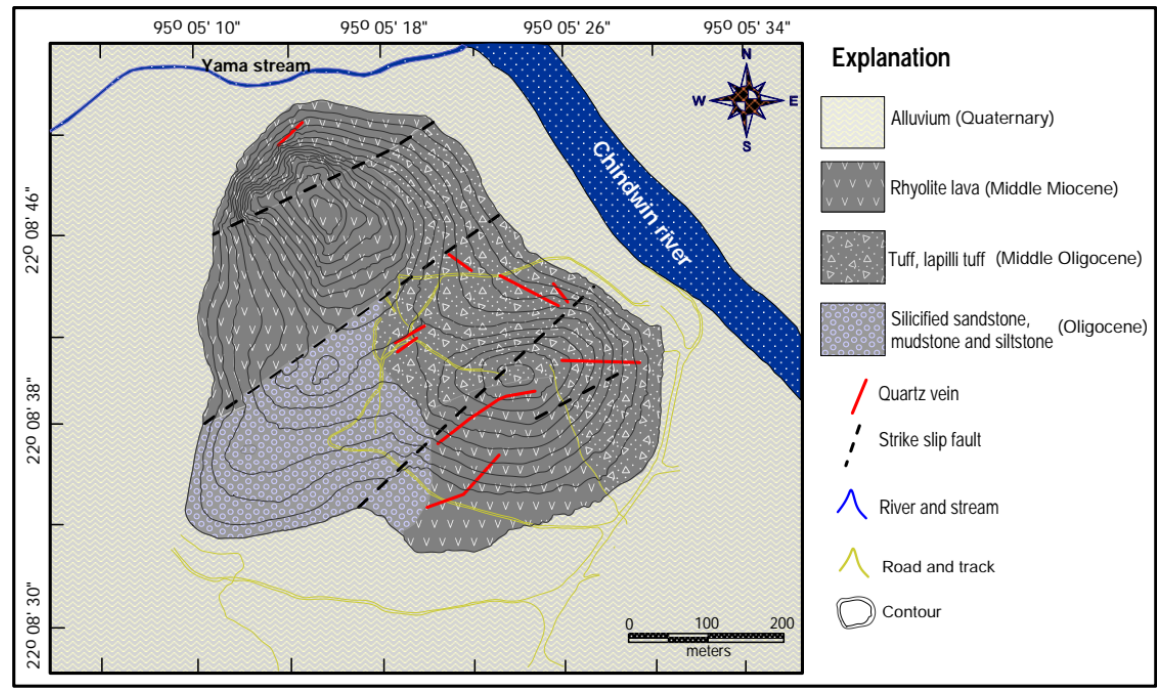

Fig 3. Geological map with distribution of quartz vein at Kyaukmyet prospect (modified from Htet, 2008).

\section{Sample Preparation and Analytical Methods}

Fluid inclusion studies have played a crucial method to reveal the conditions of hydrothermal ore-forming fluids in mineralization system and their origin. In the field study, the different types of epithermal quartz vein samples were collected systematically from the surface outcrops at Kyaukmyet prospect, Monywa copper-gold ore field in order to perform for fluid inclusion studies. Representative sample selections were carefully determined and considered to be intimately associated with ore mineralization and clear quartz samples which are accessible to recognize as well as elucidate for fluid inclusions studies under transmitted light microscope. In support of microthermometric analysis, the doubly polished thin sections were made from representative quartz vein samples in order to conduct for studying of fluid inclusion. The thickness of quartz wafers are approximately between $100-200 \mu \mathrm{m}$, depending upon the transparent quality of quartz samples. Firstly, these quartz wafers were performed by transmitted light microscope in order to examine petrography of fluid inclusion where shapes, sizes and nature of appearances and phases in the fluid inclusions were recorded on the basis of the standard citations of (Bodnar, Reynolds, \& Kuehn, 1985; Roedder, 1984). Subsequently, about 57 primary fluid inclusions from the crustiform, and banded (colloform) quartz vein samples were measured to get microthermometry data. Applying the equations of Bodnar, (1993), the values of salinity were considered from the final ice-melting temperature $(\mathrm{Tm})$. Fluid inclusions microthermometry was performed applying a Linkam TH600 combine heating and cooling stages with a range of temperature of $-196-600^{\circ} \mathrm{C}$ and reproducibility of $\pm 0.1^{\circ} \mathrm{C}$, in Kyushu University, Japan, mounted on a Nikon polarizing microscope with Axiovison software where reproducibility of temperature is $\pm 0.1^{\circ} \mathrm{C}$.

\section{Result}

\subsection{Vein Textures}

Vein textures in the Kyaukmyet prospect area can be classified into three principal categories i.e. primary, recrystallization and replacement textures according to the paragenetic as well as textural evidence which support for the elucidation of their source as well as environment of formation (Morrison, Dong, \& Jaireth, 1995). 
In this study, the most common occurrence of primary textures include comb, banded (colloform) and crustiform quartz textures (Figure 4a-e). Replacement texture consists of lattice bladed quartz texture (Figure 4f). Crustiform texture is noted as a primary texture and characterized by distinguishing feature of epithermal veins (Buchanan, 1981). This texture is commonly observed as symmetric relative to the footwall and hanging wall of the vein. The crustiform texture in quartz is composed of dominantly sequential development of banded quartz with a variety of textures including comb, lattice blade, microcrystalline and colloform (Figure 4a,b). In general, it is caused as a product of fluid conditions whereas two fluids of cooling depressurization and isothermal mixing, interaction fluidhost rocks, and the fluid boiling is the significant processes during the evolution of hydrothermal system (Buchanan, 1981). Otherwise, fluid boiling has produced in the hydrothermal fluid system as a result of dropping confining pressure. Fournier, Berger, \& Bethke, (1985), Roedder, (1984), and Bodnar et al., (1985) revealed that banded (colloform) texture is represented as a primary texture and generally characterized by a distinguishing feature an aggregates of chalcedonic in fine rhythmic bands in support of silica minerals (Figure 4c,d). It is also recognized by the occurrence of asymmetrical with their spherical, botryoidal, reniform, or mammillary surfaces indicating towards the center of the veins (Figure $4 c, d$ ). Comb texture is a primary texture and attributes to groups of parallel or subparallel euhedral quartz crystals elongated perpendicular to vein walls (Figure 4e). It is typically formed from fluid slightly supersaturated with quartz, indicating slowly changing or very mildly fluctuating of the physical conditions as well as chemical nature of the temperature, pressure and $\mathrm{pH}$ solution throughout crystals growth (Fournier et al., 1985). Simmons \& Christenson, (1994) stated that lattice bladed texture is mainly designated by a product of aggregate of platy calcite with considerable interstices each other's (Figure 4f) which results from boiling solution.

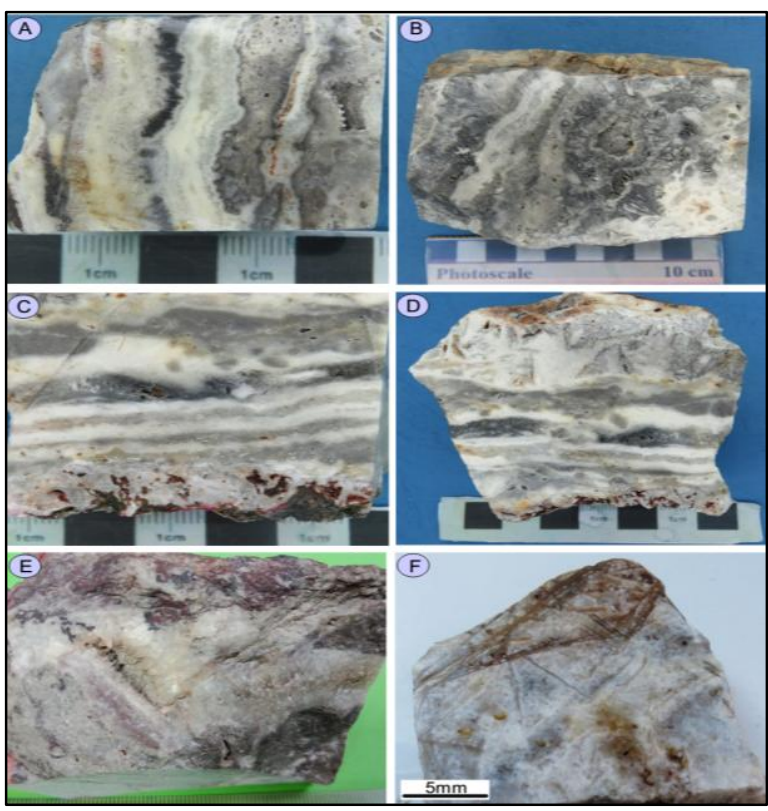

Fig. 4. Photographs showing representative epithermal quartz veins texture of (a) crustiform quartz vein in mineralization, (b) crustiform quartz vein with bladed texture , $(c, d)$ banded (colloform) quartz veins in mineralization (e) comb quartz and (f) lattice bladed texture from the Kyaukmyet prospect. (Note: figure (a) and (c) used for fluid inclusions studies)

\subsection{Petrography of Fluid Inclusion}

On the basis of their time of entrapment relative to the formation in the quartz crystals, fluid inclusions were identified as not only primary but also secondary in origin based on the standard citations of Roedder, (1984) and Bodnar et al., (1985). In support of this research, a total of 6 quartz vein samples from two different quartz veins crustiform and banded (colloform) were conducted for fluid inclusion studies. Initially, quartz wafers of crustiform and banded (colloform) quartz vein samples were analyzed under transmitted light microscope in order to identify petrography of fluid inclusion. This analyzing comprises studying on sizes, shapes, mode of appearances and fluid inclusions types respectively. Most of primary fluid inclusions occur as a variety of shapes including subrounded, negative crystal shapes and irregular shapes that are typically ranging from $5 \mu \mathrm{m}$ to a maximum $20 \mu \mathrm{m}$ and most inclusions were approximately $20 \mu \mathrm{m}$ across. A total of 57 representative primary fluid inclusions were identified and measured from the crustiform and banded (colloform) quartz vein samples. Secondary fluid inclusions were also present from the samples along with primary inclusions. They were also less common and their sizes were generally less than $5 \mu \mathrm{m}$. Microthermometric data from the secondary fluid inclusions were not deplorable.

According to their phase relations as well as their behavior during freezing and heating experiments, there are three main types of fluid inclusions are distinguished at Kyaukmyet prospect: (1) two-phase liquid-rich inclusions, (2) the coexisting of two-phase liquid-rich and vapor-rich inclusions and (3) only vapor-rich inclusions (Figure 5). In general, the liquid to vapor ratios at room temperature occur as liquid rich (10-30\% vapor phase) and vapor rich (60-90\% vapor phase) by volume (optical estimation). On the other hand, the coexistence of two-phase liquid-rich and vapor-rich fluid inclusions are point out that epithermal quartz vein samples are considered to be fluid boiling or or immiscible fluid system (Bodnar et al., 1985) (Figure 5b).

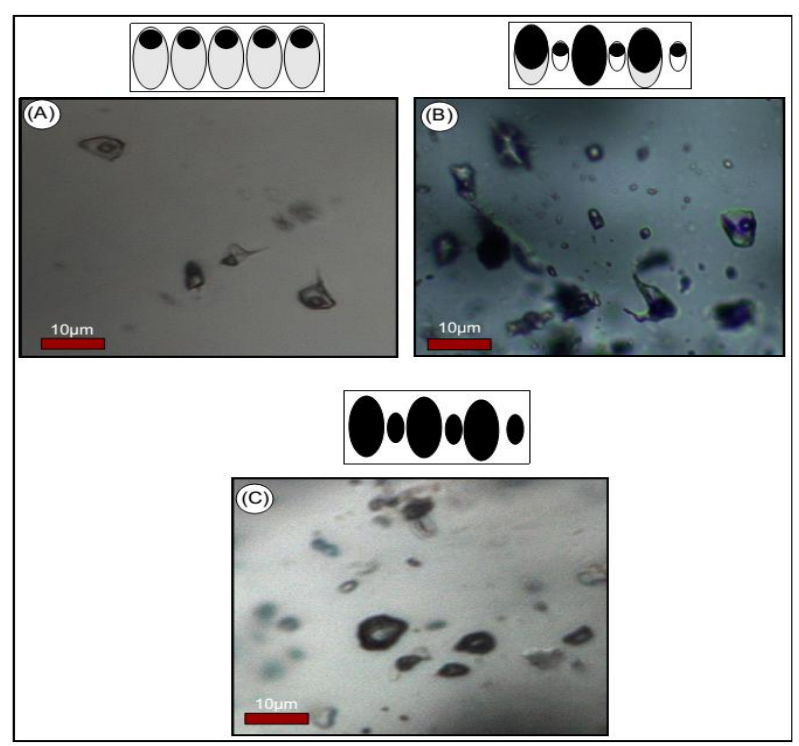

Fig. 5. Photomicrographs of (a) two-phase liquid-rich inclusions, (b) coexisting liquid-rich and vapor-rich inclusions, and (c) only vapor-rich inclusions in crustiform and banded (colloform) quartz vein samples at Kyaukmyet prospect.

\section{Discussion}

The fluid inclusion study has played a crucial role to know the estimating the temperature of homogenization 
and final ice-melting temperature. In support of this research, typical primary two-phase liquid-rich and vaporrich fluid inclusions from the crustiform and banded (colloform) quartz vein samples were systematically prepared and selected to carry out for microthemometric measurements. Fluid inclusions microthermometric analysis was undertaken on all 57 primary fluid inclusions from 6 samples of quartz veins and 2 quartz vein samples of crustiform and banded (colloform) quartz veins. Those two different quartz veins were measured to conduct for homogenization temperature (Th) and final ice-melting temperature (Tm). According to the fluid inclusions data, the homogenization temperature of primary fluid inclusions is $165-279^{\circ} \mathrm{C}$ (mean of $222^{\circ} \mathrm{C}$ ) for crustiform quartz vein and $148-282^{\circ} \mathrm{C}$ (mean of $215^{\circ} \mathrm{C}$ ) for banded (colloform) quartz vein respectively. Frequency distributions of homogenization temperature (Th) of two different quartz veins (Figure 6a and 6b) display that the mode of homogenization temperature of primary fluid inclusions give between $180-200^{\circ} \mathrm{C}$ for crustiform quartz vein and $200-220^{\circ} \mathrm{C}$ for banded (colloform) quartz vein respectively. The results of final ice melting temperatures in those vein samples from the Kyaukmyet area are varied from $-0.2^{\circ} \mathrm{C}$ to $-1.2^{\circ} \mathrm{C}$ (mean of $-0.7^{\circ} \mathrm{C}$ ). The apparent fluid inclusion salinities were interpreted based on the final icemelting temperature and by using Bodnar's equation (1993) where salinities value is ranged from 0.35 to 2.07 wt.\% $\mathrm{NaCl}$ equiv. (mean of $1.2 \mathrm{wt} \% \mathrm{NaCl}$ equiv.). In fact, salinity and homogenization temperature has played a crucial role to estimate the formation temperature, pressure of trapping, paleo-depth, fluid evolution processes (boiling, mixing and dilution) and mineral deposit types.

Wilkinson, (2001) stated that a plot diagram of homogenization temperature (Th) and salinity of fluid inclusions was considered to classify the type of deposits. The results of this study, low homogenization temperature (Th) and low salinity values suggest that a plot of these fluid inclusions microthermometric data from the Kyaukmyet prospect is considered to be consistent with epithermal deposit field (Figure 7). Meanwhile, from Th versus salinity diagram, fluid inclusion densities of the Kyaukmyet area are typically ranged from 0.7 to $0.9 \mathrm{gcm}^{-3}$ (Figure 7). Besides, the correlation between fluid inclusions salinity ( $\mathrm{wt} \% \mathrm{NaCl}$ equiv.) and homogenization temperature (Th) are likely to be revealed as a fluid evolution processes, including boiling, cooling, and mixing (Wilkinson, 2001). In a correlation diagram of $T h$ versus salinity for fluid inclusions in quartz veins from the Kyaukmyet prospect is also displayed in (Figure 8). From the diagram despite the small data set, it can be observed that the occurrence of a broad range variation of fluid inclusion salinities and homogenization temperature whereas the trend of increasing salinities with decreasing temperature.

Fluid inclusion microthermometric data shows trends of increasing salinity with decrease temperature (negative direction) indicating that an evidence of boiling condition. Salinity variation pointed out boiling or effervescence in the system, however important salinity increases might have been took place by continuous boiling in the restrained fractures (Wilkinson, 2001). On the other hand, fluid mixing also could be formed by combination or mixing with more or less saline solutions as a result of some fluid inclusions in specific temperatures showed their fluid mixing trends in figure 8.

Alternatively, the formation temperatures of quartz veins refer to first peak of histograms illustrating the primary fluid inclusion of homogenization temperatures under the boiling condition (Bodnar et al., 1985). In this place, formation temperature of the research area can be envisaged that $190^{\circ} \mathrm{C}$ for crustiform quartz vein and $210^{\circ} \mathrm{C}$ for banded (colloform) quartz vein respectively (Figure 6a and $6 \mathrm{~b}$ ). As a consequence, an estimation of formation temperature of quartz veins from the microthermometry was then interpreted for the paleo-depth of formation, and pressure of trapping applying a boiling point curve (Figure 9) (Haas, 1971). Based on the present results of formation temperature, applying the boiling point curve supported by (Haas, 1971) likewise considering of $2 \mathrm{wt} \% \mathrm{NaCl}$ equiv. and an estimate for paleo-depth of formation is $130 \mathrm{~m}$ to $210 \mathrm{~m}$ under the water table in the hydrothermal system which is equivalent to the hydrostatic fluid pressure between 12 and 19 bars respectively (Figure 9).

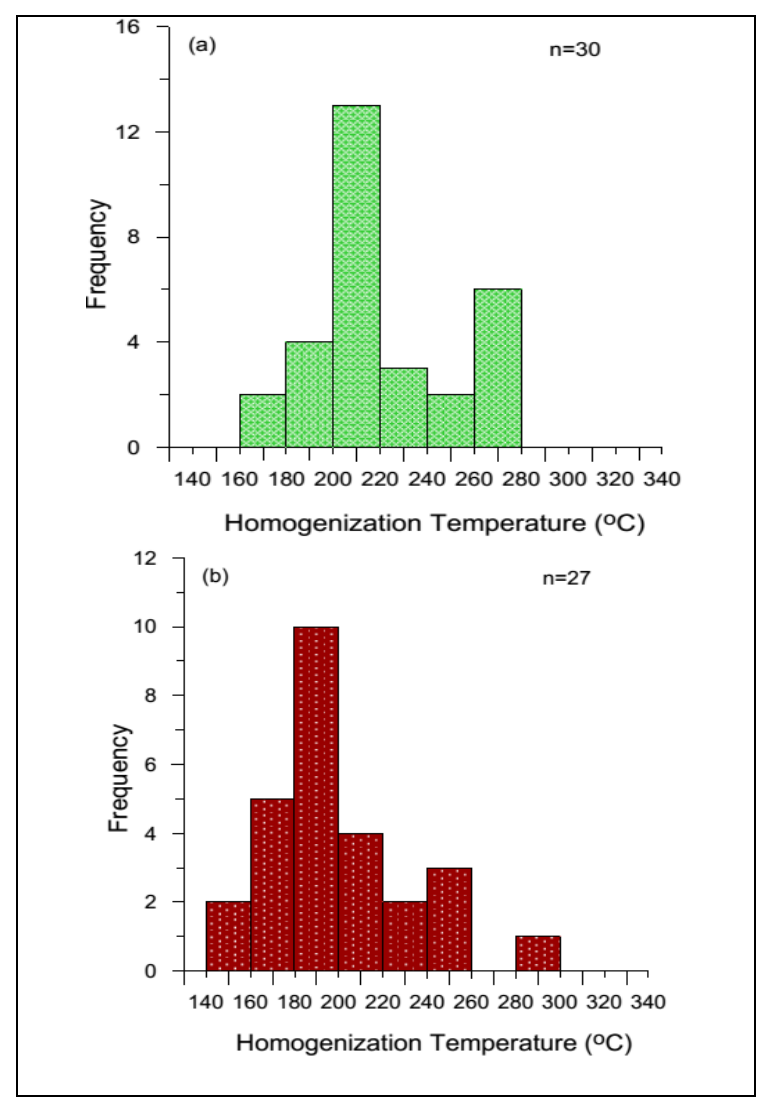

Fig 6. Th histograms of the primary fluid inclusions showing (a) banded (colloform) quartz vein and (b) crustiform quartz vein from the Kyaukmyet area ( $n=$ number of fluid inclusion).

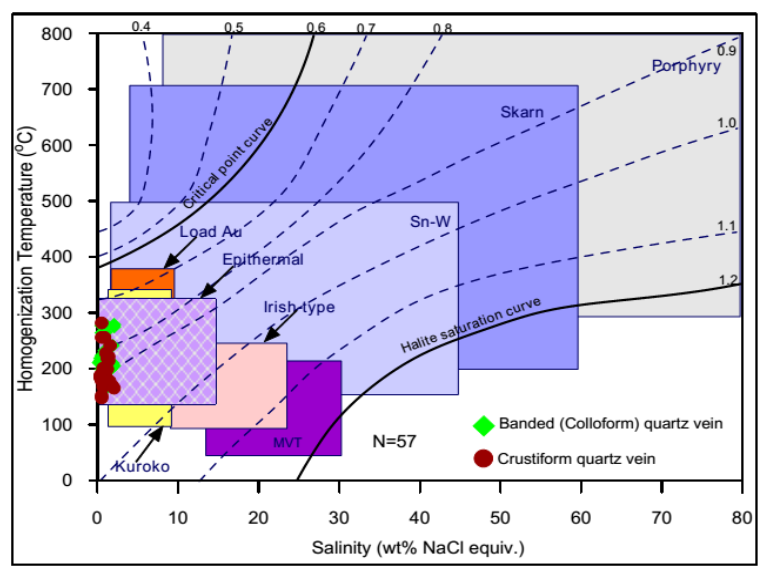

Fig 7. Th vs salinity diagram showing various types of mineral deposits (Wilkinson, 2001) and a plot of Kyaukmyet fluid inclusions points lie in the epithermal deposit field. 


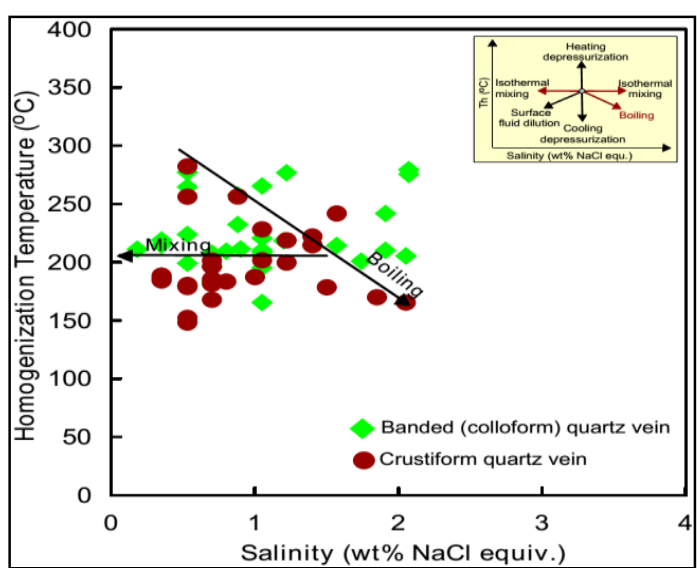

Fig 8. Salinity and Th plot diagram of the Kyaukmyet prospect epithermal quartz veins illustrating the trend of fluid evolution processes (Wilkinson, 2001).

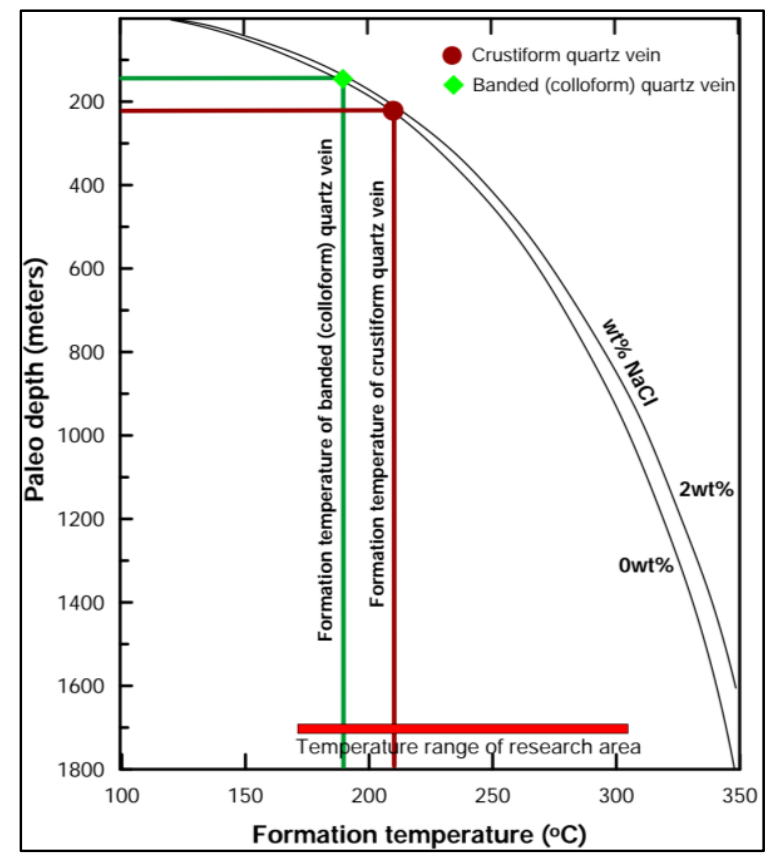

Fig 9. An estimated for paleo-depth of formation of epithermal quartz veins from the Kyaukmyet prospect applying the boiling point curve with formation temperature and salinity (after Haas, 1971).

\section{Conclusion}

On the basis of current understanding from the all available data including petrography of fluid inclusion as well as microthermometric measurements, epithermal quartz veins of the Kyaukmyet prospect are belonged to typical characters of low salinity as well as low homogenization temperature (Th) values. In support of fluid inclusion petrography, the coexisting of liquid-rich and vapor-rich fluid inclusions as well as only vapor-rich inclusions strongly suggested that they were occurred as a fluid boiling event in the hydrothermal system of the research area. In addition, the occurrence of lattice bladed texture, crustiform and banded (colloform) primary quartz veins texture that supported again for fluid boiling feature observed. The occurrence of wide range variation in fluid inclusion salinities and homogenization temperature indicated that evidence of fluid boiling condition as well as fluid mixing with more or less saline solutions. Accordingly, the primary fluid inclusions in the crustiform and (banded) colloform quartz veins possess salinities ranging from 0.35 $w t \%$ to $2.07 \mathrm{wt} \% \mathrm{NaCl}$ equiv. and homogenization temperatures from 148 to $282^{\circ} \mathrm{C}$. Plotting these data on the salinity versus homogenization temperature diagram indicated that the Kyuakmyet epithermal quartz veins formed at low salinity as well as low temperature by fluid boiling and fluid mixing during the evolution of hydrothermal fluid system. In general, low-salinity fluids can be generated by the mixing of meteoric water with magmatic fluids (Wilkinson, 2001). This suggests that the low-salinity (0.35-2.07 wt\% $\mathrm{NaCl}$ equiv.) of the Kyaukmyet epithermal quartz veins are likely to be produced by the mixing of a dominant meteoric water with minor amounts of magmatic fluid.

In a subsequent study, a compilation of salinity and homogenization temperature, the Kyaukmyet fluid inclusions of microthermoetric data is occupied in the epithermal deposit field. Furthermore, based on Th and salinity data, fluid inclusion densities for the Kyaukmyet area are between $0.7-0.9 \mathrm{~g} / \mathrm{cm}^{3}$. In contrast, the microthermometric data of primary fluid inclusions in the crustiform and banded (colloform) quartz veins from the Kyaukmyet prospect indicated that an estimation of formation temperature provides 190 to $210^{\circ} \mathrm{C}$ and their formation of paleo-depth are estimated at $130 \mathrm{~m}$ to $210 \mathrm{~m}$. Pressure of trapping at those depths are between 12 and 19 bars, respectively. All of these current conducting available data from fluid inclusions petrography and microthermometric data, formation temperature, an estimation of paleo-depth and evidence of quartz vein textures, and alteration mineral assemblages, the Kyaukmyet prospect is considered to be consistent with a low-sulfidation (LS) epithermal system.

\section{Acknowledgments}

Funding for this paper was supported by the AUN/SEED-Net (JICA program). The authors are immensely grateful to Prof. Dr. Akira Imai, Assoc. Prof. Dr. Kotaro Yonezu and laboratory members from the Kyushu University, Japan for their huge support and insightful suggestions on the data analysis as well as interpretation. The authors also would like to thank the editor and anonymous reviewers for their critical reading of the manuscript and providing valuable comments and suggestions, which greatly improve this paper.

\section{References}

Bodnar, R. ., Reynolds, T. ., \& Kuehn, C. . (1985). Fluid inclusion systematics in epithermal systems. Reviews in Economic Geology, 2, 73-73.

Bodnar, R. J. (1993). Revised equation and table for determining the freezing point depression of $\mathrm{H} 2 \mathrm{O}$ $\mathrm{NaCl}$ solutions. Geochimica et Cosmochimica Acta, $57(3), 683-684$.

Buchanan, I. J. (1981). Precious metal deposits associated with volcanic environments in the Southwest. In W. R. Dickson \& W. D. Payne (Eds.), Relations of Tectonics to Ore Deposits in the Southern Cordillera: Arizona Geological Society Digest (Vol. 14, pp. 237-262).

Fournier, R. O., Berger, B. R., \& Bethke, P. M. (1985). Geology and geochemistry of epithermal systems. SOC ECON GEOL REV ECON GEOL, 2, 45-62.

Haas, J. L. (1971). The effect of salinity on the maximum thermal gradient of a hydrothermal system at hydrostatic pressure. Economic Geology, 66(6), 940946.

Htet, W. T. (2008). Volcanic-hosted gold-silver 
mineralization in the Monywa mining district, central Myanmar. Mandalay University.

Lee, H. Y., Chung, S. L., \& Yang, H. M. (2016). Late Cenozoic volcanism in central Myanmar: Geochemical characteristics and geodynamic significance. Lithos, 245, 174-190. Elsevier.

Liu, C. Z., Chung, S. L., Wu, F. Y., Zhang, C., Xu, Y., Wang, J. G., Chen, Y., et al. (2016). Tethyan suturing in Southeast Asia: Zircon U-Pb and Hf-O isotopic constraints from Myanmar ophiolites. Geology, 44(4), 311-314. Geological Society of America.

Mitchell, A., Chung, S.-L., Oo, T., Lin, T.-H., \& Hung, C.-H. (2012). Zircon U-Pb ages in Myanmar: Magmaticmetamorphic events and the closure of a neo-Tethys ocean? Journal of Asian Earth Sciences, 56, 1-23. Retrieved

from https://linkinghub.elsevier.com/retrieve/pii/S1367 91201200185X

Mitchell, A. H. G., Htay, M. T., Htun, K. M., Win, M. N., Oo, T., \& Hlaing, T. (2007). Rock relationships in the Mogok metamorphic belt, Tatkon to Mandalay, central Myanmar. Journal of Asian Earth Sciences, 29(5-6), 891-910.

Mitchell, A. H. G., Myint, W., Lynn, K., Htay, M. T., Oo, M., \& Zaw, T. (2011). Geology of the High Sulfidation Copper Deposits, Monywa Mine, Myanmar. Resource Geology, 61(1), 1-29.

Morrison, G. W., Dong, G., \& Jaireth, S. (1995). Textural Zoning in Epithermal Quartz Veins. Klondike. Klondike Exploration Services, Townsville, Australia. Naing Oo, T., Harijoko, A., \& Setijadji, L. D. (2021). Origin of the kyaukmyet low-sulfidation epithermal gold prospect, monywa district, central myanmar. Iraqi Geological Journal, 54(1), 1-18. Union of Iraqi Geoogists.

Roedder, E. (1984). Volume 12: fluid inclusions. Reviews in mineralogy (p. 646).

Searle, M. P., Noble, S. R., Cottle, J. M., Waters, D. J., Mitchell, A. H. G., Hlaing, T., \& Horstwood, M. S. A. (2007). Tectonic evolution of the Mogok metamorphic belt, Burma (Myanmar) constrained by U-Th-Pb dating of metamorphic and magmatic rocks. Tectonics, 26(3), n/a-n/a.

Simmons, S. F., \& Christenson, B. W. (1994). Origins of calcite in a boiling geothermal system. American Journal of Science, 294(3), 361-400.

Wilkinson, J. J. (2001). Fluid inclusions in hydrothermal ore deposits. Lithos (Vol. 55). Retrieved from www.elsevier.nlrlocaterlithos

Zaw, K. (1990). Geological, petrogical and geochemical characteristics of granitoid rocks in Burma: with special reference to the associated WSn mineralization and their tectonic setting. Journal of Southeast Asian Earth Sciences, 4(4), 293-335.

Zaw, K., Swe, Y. M., Myint, T. A., \& Knight, J. (2017). Copper deposits of Myanmar. Geological Society Memoir (Vol. 48, pp. 573-588). Geological Society of London.

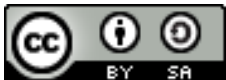

(C) 2021 Journal of Geoscience, Engineering, Environment and Technology. All rights reserved. This is an open access article distributed under the terms of the CC BY-SA License (http://creativecommons.org/licenses/bysa/4.0/). 